\title{
Entrepreneurship Policies and Poverty Reduction in Selected States of the South-East, Nigeria
}

\author{
Light IKONNE; Ngozi Nwogwugwu*, PhD. \\ Department of Political Science and Public Administration, Veronica Adeleke School of Social Sciences
}

Babcock University, Ilishan-Remo, Nigeria

\begin{abstract}
Entrepreneurship policies and programs have been noted and acknowledged globally as one of the instruments for achieving poverty reduction. As a result of the widespread poverty in the country, previous government administrations in Nigeria have at different times initiated policies and programs aimed at poverty reduction. This study investigated the relationship between entrepreneurship policies and poverty reduction in selected states of the South-East, Nigeria. Survey design was employed in the study. The population of the study were three selected states (Abia, Imo and Anambra States). Descriptive and inferential statistics were employed in analysis of data. The study found that entrepreneurship policies had joint significant effect on poverty reduction $F(1,133)=117.900$, Adj. $R^{2}=.468, p<0.05$ in Abia state. Also, in Imo State, entrepreneurship policies had significant effect on poverty reduction $F(1,120)=237.008$, Adj. $R^{2}=.663, \mathrm{P}<0.05$. Entrepreneurship policies had significant effect on poverty reduction $F(1,140)=501.709, A d j . R^{2}=.781, P<0.05$ in Anambra state. The study recommends strong and focused emphasis on youth and women empowerment through the provision of Entrepreneurship Training Centers in all the local government areas within the three selected states of the South East as this will enhance employment generation and poverty reduction.
\end{abstract}

Keywords: Entrepreneurship policies, employment generation, economic development, poverty reductions

DOI: $10.7176 / \mathrm{DCS} / 10-2-06$

Publication date: February $29^{\text {th }} 2020$

\section{Introduction}

Poverty as a critical issue has hampered on economic development in Nigeria in particular and Africa at large. Nigeria as one of the most populous countries in Africa is enormously endowed with human, agricultural and huge untapped mineral resources. Despite its endowed blessings, the country has not really utilized all its resources to its advantage rather the country has expiremented through successive governments different policies aimed at reducing poverty and unemployment among the citizens especially the youths and women. According to Adagba, et al, (2012) as cited in Ndubuisi-Okolo and Anigbuogu (2019), that the high level of involvement of Nigerian youths in various violent crimes can be attributed to the level of unemployment and poverty in the country.

Although, Nigeria is naturally blessed with both material, human and entrepreneurship capabilities but the realization of the full potentials of these opportunities have been inhibited by the implementation of inappropriate and unsustainable entrepreneurship policies as these policy interventions would have stimulated entrepreneurship development but failed. As a result, indigenous entrepreneurs become distribution agents of imported products as opposed to building internal entrepreneurial capacity for manufacturing and expert services for the nation (Adebobola, 2014, Ebiringa, 2012, Thaddeus, 2012).

In Idam (2014), entrepreneurship is seen as an emerging field of study and as an area of human endeavor, which has received increasing interest of researchers and policy makers the world over. It has equally provoked controversies over its concepts and definitions. Generally, entrepreneurship as a concept is seen not only as an effective means of combating unemployment, poverty and under-development in the developing nations, but also as a strategy for rapid economic development in both developed and developing nations (Schumpeter, 1934; Hamilton, 2000; Praag \& Versloot, 2007). Entrepreneurship serves as a source of income generation and poverty reduction for some major groups both rural and urban inhabitants without recognized paid jobs (Ihugba, Odii, \& Njoku, 2014) and also serves as an element of change and transformation of economic, cultural and societal development (Moghimi, 2008).

The importance of entrepreneurship policies in several economies globally cannot be overemphasized; as such majority of countries worldwide have established such policies to support entrepreneurship in their various countries (Gangi \& Timan, 2013). It has been established that entrepreneurship policies are instruments for job creation as well as economic development (Friedman, 2011). The 2012 Global Entrepreneurship Monitor (GEM) empirically identified Nigeria as one of the most entrepreneurial countries in the world. The study shows that 35 out of every 100 Nigerians are engaged in some kind of entrepreneurial activity or the other. The only countries that have better records in sub-sahara Africa are Malawi (36\%), Uganda (36\%), Ghana (37\%) and Zambia $(41 \%)$.

In Nigeria, studies have been carried out to show the positive impacts of entrepreneurship policies on the 
problem of high unemployment rate, high level of poverty and slow economic development rate (Ajiboshin, Raimi, Raheem, and Igwe, 2013; Salami, 2013; Thaddeus, 2012; Abimbola \& Agboola, 2011; Agboli \& Ukaegbu, 2006; Ariyo, 2005; Adejumo, 2001). Government at all levels have come up with several policies such as National Directorate of Employment, Mass Mobilization for Self-Reliance and Economic Recovery, Bank of Industry, Small and Medium Enterprises Development Agencies (SMEDAN), Entrepreneurship Development Centre (EDC) and the Youth Enterprise With Innovation in Nigeria (YOUWIN) designed to stimulate entrepreneurship to be able to cushion the hostile effects of unemployment, youth restiveness, terrorism, kidnapping and so many other social vices within our various localities. The negative impact caused by these vices are more evident in developing countries when compared to developed nations where improved macro-economic stability had been experienced in the past (Sevastapulo 2014, Adebobola, 2014).

In some developed countries of the world such as the United States of America, Britain and China, entrepreneurship is considered a formidable instrument for socio-economic empowerment, job creation and poverty reduction. Such impact of entrepreneurship is also evidently shown in countries which reported declines in the unemployment levels because they have higher level of increase in entrepreneurial initiative index (Hussain \& Norashidah, 2015).

Entrepreneurship policies have at various times been initiated by government of Nigeria to ensure the reduction in unemployment and to encourage economic development. Even international bodies such as the World Bank and IMF have also contributed to the efforts directed at reducing unemployment. For instance, a Partnership Strategy that covers a four-year period from 2014 to 2017 was approved in April 2014 by the Board of Executive Directors of the World Bank to assist the Nigerian government. It focused on three key strategies that aimed to foster entrepreneurship development, reduce poverty and unemployment (The Guardian, 2015). The study examined the relationship between entrepreneurship policies and poverty reduction in selected states of South East, Nigeria.

\section{LITERATURE REVIEW}

2.1 Entrepreneurship policy

Policy is a part of the environmental factors that supports the development of entrepreneurship of any country world over. Stevenson and Lundström (2001, p. 11) noted that entrepreneurship policy has become an emerging field of the economic development arena. Global attention in entrepreneurship policy has equally increased ever since. Lundstrom and Stevenson (2005), define entrepreneurship policy as policy measures taken to stimulate entrepreneurship; that are aimed at the pre-start, the start-up and post-start-up phases of the entrepreneurial process; designed and delivered to address the areas of motivation, opportunity and skills; with the principal aim of encouraging more people to start their own businesses (Storey, 2008). Entrepreneurship policies are the plans or courses of action, established by government in order to influence and enhance entrepreneurial decisions and actions (Audretsch, Grilo, \& Thurik, 2007; Vesper, 1983; Klapper, Amit, \& Guillén, 2010).

Oni \& Daniya, (2012), as cited in Margaret, (2018), asserted that governments of most countries especially developing countries like China, Brazil, Saudi Arabia, Malaysia and Nigeria have in the past invested efforts and resources in initiating policies expected to improve entrepreneurship development. For instance, the case of the Chinese government which has made resolute efforts through policies and resources on the development of high technology businesses (Obaji \& Olugu, 2014). The Brazilian entrepreneurship movement which has improved greatly as a result of government policies aimed towards developing the low-tech businesses as well as high technological oriented firms (Etzkowitz, 2009).

However, in Nigeria, different administrations at various periods have initiated programmes and policies aimed towards developing its entrepreneurship. Several developmental and financial strategies were employed in this process as well. Despite these efforts by the government, the programme has been unsuccessful as a result of domineering bureaucratic processes, corruption, insufficient and ineffectual infrastructural amenities (Ihugba, Odii, and Njoku 2014, Obaji \& Olugu, 2014).

However, in the light of the government's efforts for poverty reduction and to enable the private sector perform her expected role as the driver of economic development, the government which has a fundamental responsibility of promoting growth and development came up with policies to encourage private sector initiatives and participation. According to Idam, (2014), the major anti-poverty policies and programmes by successive governments in Nigeria include the following;

National Enterprise Development Programme (NEDEP) which is the centrepiece of the Government's efforts at poverty reduction and a Federal government initiative launched in 2013. The programme was expected to provide business development services, entrepreneurship training, access to affordable finance and core craft skills acquisition. One of the programme's main objective is to solve the problems of unemployment, through technical and vocational training and the empowerment of the unemployed by providing access to start-up funds.

The National directorate of employment (NDE) which was established in 1987 by CAP 250 of the law of Federal Republic of Nigeria (Military decree) and has the main task of creating job opportunities and 
implementing government polices directed at solving the growing unemployment problem of the economy. Baba, Dickson, \& Kromtit (2014), recalled the programme was to address four major areas to combat unemployment:

i). Small Scale Enterprises programme: This is for the graduate and mature unemployed people. ii). Vocational / entrepreneurship skills development programme: This is for National Open Apprenticeship, School on wheels, Waste to Wealth, Resettlement and disabled persons scheme and so forth.

iii). Rural Employment Promotion Programme: Graduate Agriculture Self- Employment Programme. iv). Special public works programme: Oyemoni, (2003), stressed that NDE, (1986) has trained more than two million unemployed and provided business training for not less than 400,000 Nigerians. Since its establishment in 1986, NDE has been able to record some achievements in the fulfillment of its mandate from designing employment to generating programmes and training schemes to empower thousands of unemployed persons in our society.

The Small and Medium Enterprises Equity Investment Scheme was approved by the Bankers' Committee at its 246th meeting held on 21st December 1999 and was formally launched on August 21, 2001, by former president Olusegun Obasanjo (Sanusi, 2003). With its objectives as to address some of the factors militating against the attainment of the full potentials of SMEs. This was a response to government entrepreneurship policies direction towards improving banks participation in the growth and development of Small and Medium Enterprises (SMEs) (Sanusi, 2003).

The Small and Medium Enterprises Development Agency of Nigeria (SMEDAN) was established in 2003, to facilitate the promotion and development of Micro, Small and Medium Scale Enterprises (MSMEs) sector of the Nigerian economy (SMEDAN, 2011). The overall objective was reducing poverty through wealth and job creation to facilitate socio-economic transformation or national economic development, the Micro, Small and Medium Enterprise are perceived as engine of socio-economic transformation in both developed and developing countries.Ekwem (2011), listed the functions of SMEDAN as contained in the enabling Act of 2003 which is summarized as follows: Stimulating, coordinating and monitoring the development of the MSMEs sector, initiating and articulating policy ideas for micro, small and medium enterprises' growth and development, facilitating and promoting development programmes or initiative, support services in other to accelerate the modernization of MSME operations in the country, serving as vanguard for poverty reduction, rural industrialization, job creation and enhance sustainable livelihoods.

The YouWiN Programme was established in 2011 with the collaboration of the Ministry of Finance, the Ministry of Communication Technology (CT), the Ministry of Youth Development and the Ministry of Women Affairs and Social Development which launched annual Business Plan Competition (BPC) for aspiring young entrepreneurs to showcase their business expertise, skills and aspirations to business leaders, investors and mentors in Nigeria (Tende, 2014). A major objective of the Programme is to generate jobs by encouraging aspiring entrepreneurial youths in Nigeria to develop and execute business ideas that will lead to job creation (Akpedji, 2015, YouWIN, 2013).

However, some positive achievements have been recorded by the Nigerian government in her efforts at poverty reduction in the areas of agricultural and industrial development, employment generation and wealth creation, youth empowerment through skill acquisition training by the Small and Medium Scale Enterprise development Agency of Nigeria (SMEDAN), the provision of "strategies for the eradication of absolute poverty in Nigeria" by the National Poverty Eradication Programme (NAPEP), The provision of financial assistance for the establishment of large, medium and small enterprises; as well as expansion, diversification and modernization of existing enterprises; and rehabilitation of ailing industries by the bank of industry. Despite all these efforts by the government and its development agaencies, the incidence of poverty in Nigeria remains very high. A number of factors have been listed as have contributed to the ineffectiveness of the successive governments' efforts at poverty reduction. These factors include poor Policy implementation, policy instability and inconsistency (Osotimehin, Jegede, Akinlabi and Olajide, 2012), Public sector dominance, unstable governmental system, lack of financial support from relevant agencies, corruption (Ocheni and Gemade, (2015),Adebisi and Gbegi, 2013), Poor funding; Ihugba, Odii and Njoku (2013) infrastructural decay; Okeke and Eme (2014), multiple taxation and levies (Gbandi and Amissah, (2014); Agwu and Emeti, (2014); Etuk, Etuk and Baghebo, (2014); Adebisi and Gbegi, (2013) and the high cost of doing business in Nigeria, Duru (2011) and World Bank (2008). Atawodi and Ojeka, (2012).

\subsection{Poverty reduction}

Poverty has currently been seen as "the world's greatest threat to peace and stability even more than terrorism and other highly publicized struggles" (Oloyede, 2014; Omoniyi, 2013). According to Sachs (2009) in Omoniyi (2013), "more than eight million people around the world die each year because they are too poor to stay alive". According to Omadjohwoefe (2012) as cited in Anigbogu et al (2016), "Nigerian poverty profile has been on upward trend over the past decades. For example, "poverty level in Nigeria rose from $28.1 \%$ in 1980 to $46.3 \%$ in 1985. In 1992 it was $42.7 \%$ it rose to $65.6 \%$ in 1996 and later came down to $54.4 \%$ in 2004. Between 2004 and 
2010, with an estimated population of about One Hundred and Sixty Million people (160million), about One Hundred and Twenty Million people were reported to be poor"(National Bureau of Statistics, 2012).

To World Bank (2013), poverty is being unable to meet basic needs requirements (such as physical: food, healthcare, education, shelter etc and non-physical: participation, identity etc.) for a meaningful life. Bornstein and Davis (2010) as cited in Mohammed \& Ndulue (2017), "poverty reduction is often used as a short-hand for promoting economic growth that will permanently lift as many people as possible over a poverty line. Its aims to improve the quality of life for those individuals currently living in poverty. Poverty reduction refers to efforts aimed towards reducing the magnitude of poverty defined in terms of the proportion of the individuals living below the poverty line. Measures intended to permanently lift people out of poverty Prahalad and Hammond (2012)

The theory of poverty reduction according to Mohammed \& Ndulue (2017), can be viewed in three contrasting definitions namely; the objectivists, constructivists, and mixed perspectives of conceptualizing poverty reduction.

Objectivist theory of Poverty Reduction describes poverty reduction as a social strategy through a process of scientific enquiry and values which are geared towards alleviating poverty (Manis, 1976). Here, the process focuses solely on the strategies of alleviating poverty through investigation, observation and experimentation.

The Constructionists theory of Poverty Reduction views it as the activities of individuals or groups towards identifying the root causes of poverty and finding a lasting solution to curbing it. While the mixed theory of poverty reduction views poverty reduction as both strategy highlighted by a process of scientific enquiry and values which are geared towards alleviating poverty and as the activities of individuals or groups towards identifying the root causes of poverty and finding a lasting solution to curbing it (Henslin, 2003).

\section{Theoretical Framework}

The Development Theory of Poverty Reduction.was adopted for the purpose of analysis of the effect of entrepreneurship policies on poverty reduction. Development Theory of Poverty Reduction holds that "most countries progress through similar stages of development in an effort to curb poverty (Potterovich, \& Popov,2012, p.14). According to Misango \& Ongiti (2013), there are four stages of development. The "preindustrial stage which is characterized by high death and birth rates but not much of economic development. The country begins to develop in stage two where the death rates decline and there is improved food supply and proper sanitation. Birth rates begin to fall in stage three because people are now able to practice family planning. There is also urban development, increase in education, and parents begin to invest. This has made it possible for developed countries to assist the underdeveloped countries so as to free them from persistence donor dependence. Stage four is characterized by low birth and death rates. There is increased development at this stage".

This theory explains the many developmental processes an entrepreneur (a business owner) undertakes in entreprenurship development in an effort to reduce poverty. The entrepreneur begins with ideas which is necessary as any business needs a good idea to start. The idea might not necesaaaily have to be unique. Every business requires finance or start up capital and employment of people in the early months of its existence; the business owner definitely is one of the workers and finally the business idea needs to be converted into strategy.

\section{Methodology}

The study employed convergent parallel design, which is a mixed method design. The population of study was the three selected states (Abia, Anambra and Imo) from South-East, geo-political zone. For the purpose data collection, six Local governments were purposively selectedfor being the major entrepreneurial hubs of the states (two from each of the three states). The selected local governments are: Aba North and Aba South, Nnewi South and Onitsha North, Orlu and Owerri West Local governments.

\subsection{Sample size}

In determining the sample size, the researcher adopted Taro Yamane (1967) formula. A 95\% confidence level and level of maximum variability $(\mathrm{P}=0.5)$ are assumed. Where $\mathrm{n}$ is the sample size, $\mathrm{N}$ is the population size, and $\mathrm{e}$ is the level of precision (allowable error) that is $5 \%$ or 0.05 .

The Taro Yamane formula is stated below as:

$$
\mathrm{n}=\frac{\mathrm{N}}{1+\mathrm{N}(\mathrm{e})^{2}}
$$

Where $\mathrm{n}=$ sample size; $\mathrm{N}=$ Total population of the study; $\mathrm{e}=$ Error of margin at $5 \%$ level or level of precision @ (0.05), we have

$\mathrm{n}=1, \underline{514,000}$

$$
1+514,000(0.05)^{2} \text {. }
$$

$\mathrm{n}=1, \underline{514,000}$ 
$\mathrm{n}=399.89$, therefore $\mathrm{n}=400$.

\section{Results and Discussion}

Research question: What is the relationship between entrepreneurship policies and poverty reduction in the selected states of the south east?

Table 1: Relationship between entrepreneurship policies and poverty reduction

\begin{tabular}{|c|c|c|c|c|c|}
\hline Abia & $\begin{array}{l}\text { Strongly } \\
\text { Agree }(\%)\end{array}$ & $\begin{array}{l}\text { Agree } \\
(\%)\end{array}$ & $\begin{array}{l}\text { Undecided } \\
(\%)\end{array}$ & Mean & SD \\
\hline $\begin{array}{l}\text { NDE reduced poverty through creating of } \\
\text { opportunities in agricultural production sector. }\end{array}$ & $52(38.8)$ & $82(61.2)$ & & 4.39 & .489 \\
\hline $\begin{array}{l}\text { NAPEP reduced poverty through creation of jobs in } \\
\text { agricultural sector. }\end{array}$ & $47(35.1)$ & $87(64.9)$ & & 4.35 & 479 \\
\hline NDE created jobs for many young graduates & $39(29.1)$ & 95(70.9) & & 4.29 & .456 \\
\hline $\begin{array}{l}\text { Entrepreneurship policies and programmes have } \\
\text { facilitated the growth of the waste -to- wealth } \\
\text { programmes in my state. }\end{array}$ & $39(29.1)$ & $95(70.9)$ & & 4.29 & .456 \\
\hline $\begin{array}{l}\text { Entrepreneurship policies facilitated the success of } \\
\text { NAPEP AND YOU-WIN programmes. }\end{array}$ & $32(23.9)$ & $102(76.1)$ & & 4.24 & .428 \\
\hline Imo & $\begin{array}{l}\text { Strongly } \\
\text { Agree }(\%)\end{array}$ & $\begin{array}{l}\text { Agree } \\
(\%)\end{array}$ & $\begin{array}{l}\text { Undecided } \\
(\%)\end{array}$ & Mean & $\mathrm{SD}$ \\
\hline NDE created jobs for many young graduates & $12(9.9)$ & $75(62)$ & $34(28.1)$ & 3.26 & 1.446 \\
\hline $\begin{array}{l}\text { NDE reduced poverty through creating of } \\
\text { opportunities in agricultural production sector. }\end{array}$ & $90(74.4)$ & $31(25.6)$ & & 3.23 & 1.315 \\
\hline $\begin{array}{l}\text { NAPEP reduced poverty through creation of jobs in } \\
\text { agricultural sector. }\end{array}$ & $87(71.9)$ & $3(2.5)$ & $31(25.6)$ & 3.21 & 1.310 \\
\hline $\begin{array}{l}\text { Entrepreneurship policies and programmes have } \\
\text { facilitated the growth of the waste -to- wealth } \\
\text { programmes in my state. }\end{array}$ & $84(69.4)$ & $6(5)$ & $31(25.6)$ & 3.18 & 1.304 \\
\hline $\begin{array}{l}\text { Entrepreneurship policies facilitated the success of } \\
\text { NAPEP AND YOU-WIN programmes. }\end{array}$ & $9(7.4)$ & $73(60.3)$ & $39(32.2)$ & 3.11 & 1.482 \\
\hline Anambra & $\begin{array}{l}\text { Strongly } \\
\text { Agree }(\%)\end{array}$ & $\begin{array}{l}\text { Agree } \\
(\%)\end{array}$ & $\begin{array}{l}\text { Undecided } \\
(\%)\end{array}$ & Mean & $\mathrm{SD}$ \\
\hline $\begin{array}{l}\text { Entrepreneurship policies and programmes have } \\
\text { facilitated the growth of the waste -to- wealth } \\
\text { programmes in my state. }\end{array}$ & $13(9.2)$ & $95(67.4)$ & $33(23.4)$ & 3.39 & 1.356 \\
\hline $\begin{array}{l}\text { NDE reduced poverty through creating of } \\
\text { opportunities in agricultural production sector. }\end{array}$ & $18(12.8)$ & $86(61)$ & $37(26.2)$ & 3.34 & 1.438 \\
\hline $\begin{array}{l}\text { Entrepreneurship policies facilitated the success of } \\
\text { NAPEP AND YOU-WIN programmes. }\end{array}$ & $16(11.3)$ & $88(62.4)$ & $37(26.2)$ & 3.33 & 1.427 \\
\hline NDE created jobs for many young graduates & $16(11.3)$ & $88(62.4)$ & $37(26.2)$ & 3.33 & 1.427 \\
\hline $\begin{array}{l}\text { NAPEP reduced poverty through creation of jobs in } \\
\text { agricultural sector. }\end{array}$ & $9(6.4)$ & $95(67.4)$ & $37(26.2)$ & 3.28 & 1.384 \\
\hline
\end{tabular}

\section{Source: Field survey (2019)}

The result in table above explains the relationship between entrepreneurship policies and poverty reduction in the selected states of the south east. The analysis shows that in Abia state, NDE reduced poverty through creating of opportunities in agricultural production sector (mean=4.39) and NAPEP reduced poverty through creation of jobs in agricultural sector (mean=4.35). In Imo state, NDE created jobs for many young graduates $($ mean=3.26) and reduced poverty through creating of opportunities in agricultural production sector $($ Mean $=3.23)$.

However, in Anambra state, the relationship between entrepreneurship policies and poverty reduction is that entrepreneurship policies and programmes have facilitated the growth of the waste -to- wealth programmes $($ mean $=3.39)$ and that NDE reduced poverty through creating of opportunities in agricultural production sector (mean=3.34).

Our findings revealed that on the average, the respondents in all three states agreed that entrepreneurship policies and programs of the Nigerian government have contributed to poverty reduction through creating of opportunities in agricultural production sector, NAPEP reduced poverty through creation of jobs in agricultural sector. In Imo state, NDE reduced poverty through creation wealth creation opportunities for many young 
graduates. In Anambra state, entrepreneurship policies reduced poverty through the facilitation of the growth of the waste to wealth programs.

The study also found that there is a significant effect of entrepreneurship policies on poverty reduction in the selected states of South East. Entrepreneurship policies facilitated the creation of conducive environment for people to access the various opportunities for wealth creation, thereby overcoming poverty. The findings as corroborated in earlier studies by Edobor (2013) that entrepreneurship has proven to be a solution for poverty reduction through employment generation and wealth creation.

This study identified entrepreneurship policies as one of the major backbones of the Nigerian economic development especially in the South East region of the country. The contributions of the small and medium scale enterprises in industrial sector to the Nigeria's Gross Domestic Product (GDP) are valued at about 37\%, thereby making it the second largest contributor to the Nation's GDP after the oil sector (SMEDAN, 2009).

The study discovered that the federal government of Nigeria through its developmental agencies initiated entrepreneurship policies to tackle unemployment and poverty. Some of these policies include: National Enterprise Development Programme (NEDEP), National Directorate of Employment (NDE), Small and Medium Enterprises Development Agency of Nigeria (SMEDAN), Small and medium industries equity investment scheme (SMEIS), Youth enterprise with innovation in Nigeria (YOUWIN), Rural Finance Institution Building Programme (RUFIN), and National Industrial Revolution Plan (NIRP).

These policies no doubt have laudable objectives to make impactful contributions towards job creation and poverty reduction by providing the needed training, financial assistance, which are considered relevant to entrepreneurship development of the citizens.

Table 2: Influence of demographic variables on poverty reduction

\begin{tabular}{|c|c|c|c|c|c|}
\hline \multicolumn{6}{|c|}{ Influence of demographic variables on poverty reduction in Abia state } \\
\hline \multirow{2}{*}{$\begin{array}{ll}\text { Demographic } & \text { variables } \\
\text { (Independent) } & \end{array}$} & \multicolumn{2}{|c|}{ Unstandardized Coefficients } & \multirow{2}{*}{$\begin{array}{c}\begin{array}{c}\text { Standardized } \\
\text { Coefficients }\end{array} \\
\text { Beta }\end{array}$} & \multirow[t]{2}{*}{$\mathrm{t}$} & \multirow[t]{2}{*}{ Sig. } \\
\hline & $\mathrm{B}$ & Std. Error & & & \\
\hline \multirow{5}{*}{$\begin{array}{l}\text { (Constant) } \\
\text { Gender } \\
\text { Marital Status } \\
\text { Educational Qualifications } \\
\text { Age }\end{array}$} & 20.384 & 1.000 & \multirow{5}{*}{$\begin{array}{r}-.009 \\
-.039 \\
.043 \\
.186 \\
\end{array}$} & 20.383 & .000 \\
\hline & -.026 & .262 & & -.099 & .922 \\
\hline & -.111 & .245 & & -.454 & .651 \\
\hline & .084 & .170 & & .496 & .621 \\
\hline & .355 & .170 & & 2.095 & .038 \\
\hline \multicolumn{6}{|l|}{$\mathrm{F}=1.191$. Adjusted $\mathrm{R}^{2}=.006$} \\
\hline \multicolumn{6}{|c|}{ Influence of demographic variables on poverty reduction in Imo state } \\
\hline \multirow[t]{3}{*}{ Demographic variables } & \multirow{2}{*}{\multicolumn{2}{|c|}{ Unstandardized Coefficients }} & Standardized & \multirow[t]{3}{*}{$\mathrm{t}$} & \multirow[t]{3}{*}{ Sig. } \\
\hline & & & Coefficients & & \\
\hline & $\mathrm{B}$ & Std. Error & Beta & & \\
\hline \multirow{5}{*}{$\begin{array}{l}\text { (Constant) } \\
\text { Gender } \\
\text { Marital Status } \\
\text { Educational Qualifications } \\
\text { Age }\end{array}$} & 20.531 & 2.762 & \multirow{5}{*}{$\begin{array}{r}-.379 \\
.296 \\
-.176 \\
-.017\end{array}$} & 7.434 & .000 \\
\hline & -5.021 & 1.161 & & -4.323 & .000 \\
\hline & 3.575 & 1.573 & & 2.273 & .025 \\
\hline & -1.251 & .703 & & -1.780 & .078 \\
\hline & -.110 & .896 & & -.122 & .903 \\
\hline \multicolumn{6}{|c|}{$\mathrm{F}=6.166$, Adjusted $\mathrm{R}^{2}=.147$} \\
\hline \multicolumn{6}{|c|}{$\begin{array}{r}\text { Influence of demographic variables on poverty reduction in Anambra state } \\
\end{array}$} \\
\hline \multirow[t]{3}{*}{ Demographic variables } & \multirow{2}{*}{\multicolumn{2}{|c|}{ Unstandardized Coefficients }} & Standardized & \multirow[t]{3}{*}{$\mathrm{t}$} & \multirow[t]{3}{*}{ Sig. } \\
\hline & & & & & \\
\hline & $\mathrm{B}$ & Std. Error & Beta & & \\
\hline \multirow{5}{*}{$\begin{array}{l}\text { (Constant) } \\
\text { Gender } \\
\text { Marital Status } \\
\text { Educational Qualifications } \\
\text { Age }\end{array}$} & -2.078 & 4.239 & \multirow{6}{*}{$\begin{array}{r}-.054 \\
.010 \\
.341 \\
.248\end{array}$} & \multirow{6}{*}{$\begin{array}{r}-.490 \\
-.589 \\
.118 \\
3.629 \\
3.011\end{array}$} & \multirow{6}{*}{$\begin{array}{l}.625 \\
.557 \\
.906 \\
.000 \\
.003\end{array}$} \\
\hline & -.728 & 1.236 & & & \\
\hline & .122 & 1.031 & & & \\
\hline & 2.544 & .701 & & & \\
\hline & \multirow[t]{2}{*}{3.337} & \multirow[t]{2}{*}{1.108} & & & \\
\hline $\mathrm{F}(4,140)=6.797$, Adj. $\mathrm{R}^{2}=.142$ & & & & & \\
\hline
\end{tabular}

Dependent Variable: Poverty Reduction

As shown in table above, demographic variables had no joint significant effect on poverty reduction $\mathrm{F}(4$, $133)=1.191$, Adj. $\mathrm{R} 2=.006, \mathrm{p}>0.05$. Age $(\beta=.186, t(133)=2.095 . p<.05)$ had a significant influence on poverty reduction in Abia state; whereas, gender $(\beta=-.009, t(133)=-.099, p>.05)$, marital status $(\beta=-.039, t(133)=-.454$, 
$p>.05)$, and educational qualification $(\beta=.043, t(133)=.496, p>.05)$ had no significant influence on poverty reduction in the state. The result for Imo State shows that demographic variables had a joint significant effect poverty reduction $\mathrm{F}(4,120)=6.166$, Adjusted $\mathrm{R} 2=.147, \mathrm{P}<0.05$. Gender $(\beta=-.379, t=-4.323, p<.05)$ had a negative influence while marital status $(\beta=.296, t=2.273, p<.05)$ had significant influence on poverty reduction; educational qualification $(\beta=-.176, t=-1.780, p>.05)$ and age $(\beta=-.017, t=-.122, p>.05)$ were found to have no significant influence on poverty reduction in Imo state. In the case of Anambra State, demographic variables had a joint significant effect on poverty reduction $\mathrm{F}(4,140)=6.797$, Adj. $\mathrm{R} 2=.142, \mathrm{p}<0.05$. Gender $(\beta=-.054, t=-.589$, $p>.05)$ and marital status $(\beta=.010, t=.118, p>.05)$ were found to have no significant influence on poverty reduction in Anambra state; while educational qualification $(\beta=.341, t=3.629, p<.05)$ and age $(\beta=.248, t=3.011$, $p<.05)$ had significant influence on poverty reduction and could account for $34.1 \%$ and $24.8 \%$ respectively of the variations in poverty reduction in Anambra state.

Table 3: Effect of entrepreneurship policies on poverty reduction

\begin{tabular}{|c|c|c|c|c|c|c|}
\hline $\mathrm{S} / \mathrm{N}$ & Hypotheses & $N$ & $B$ & $\operatorname{Adj.} R^{2}$ & $F$ & Sig \\
\hline & \multicolumn{6}{|c|}{ Abia State } \\
\hline & Effect of Entrepreneurship policies on poverty reduction & 133 & .687 & .468 & 117.910 & .000 \\
\hline & \multicolumn{6}{|l|}{ Imo State } \\
\hline & Effect of Entrepreneurship policies on poverty reduction & 120 & .816 & .663 & 237.008 & .000 \\
\hline & \multicolumn{6}{|l|}{ Anambra State } \\
\hline & Effect of Entrepreneurship policies on poverty reduction & 140 & .885 & .781 & 501.709 & 0.000 \\
\hline
\end{tabular}

Dependent variable: poverty reduction

Predictor variables: Entrepreneurship policies

Source: Field survey (2019)

The results on table 3 above reveal that entrepreneurship policies had a joints significant effect on poverty reduction $F(1,133)=117.900, A d j . R^{2}=.468, p<0.05$ in Abia state. Also, in Imo State, entrepreneurship policies had significant effect on poverty reduction $F(1,120)=237.008, A d j . R^{2}=.663, \mathrm{P}<0.05$. In the same vein, entrepreneurship policies had a significant effect on poverty reduction $F(1,140)=501.709, \operatorname{Adj} . R^{2}=.781, P<0.05$ in Anambra state. This implies that, formulation and implementation of strategically planned entrepreneurship policies would lead to higher rate of poverty reduction in the three selected states of the South-East, Nigeria. Therefore, the null hypothesis is rejected and is hereby restated that entrepreneurship policies has a significant effect on poverty reduction in the three selected states of South-East, Nigeria.

\section{Conclusion and recommendation}

The study concludes that entreprenurship policies plays a major role in poverty reduction in the selected states in South-East, Nigeria. Entrepreneurship policies when well implemented result in poverty reduction, and by extension facilitate the attainment of economic development. The different entrepreneurship programmes of the federal government such as; National Enterprise Development Programme (NEDEP), National Directorate of Employment (NDE), Small and Medium Enterprises Development Agency of Nigeria (SMEDAN), Small and medium industries equity investment scheme (SMEIS), Youth enterprise with innovation in Nigeria (YOUWIN), Rural Finance Institution Building Programme (RUFIN), and National Industrial Revolution Plan (NIRP) had different impact on the selected states. The level of commitment of the various state governments to particularly programmes to a large extent determined the effectiveness of the implementation of such programmes in their State.

The study however recommends the following:

i) There is the need for strong and focused emphasis on self-reliance and self-employment of individuals especially the youths and women through the provision of entrepreneurship training centers in all the local government areas within the three selected states of the South East as this will enhance employment generation and poverty reduction.

ii) The government should create an enabling business environment for the needed industrialization base that is required to diversify her economy as it is a vital area to consider in the evaluation of entrepreneurship performance. Private individuals and other stake holders must equally help the government in her efforts in diversifying the economy.

\section{References}

Abimbola, O. H. \& Agboola, G. M. (2011), "Environmental factors and entrepreneurship development in Nigeria" Journal of Sustainable Development in Africa, 13(4), 166-176.

Adebisi, J. F. \& Gbegi, D. O. (2013). "Effects of tax avoidance and tax evasion on personal income tax administration in Nigeria", American Journal of Humanities and Social Sciences, 1(3), 125 - 134.

Adejumo, G. (2001), "Indigenous entrepreneurship development in Nigeria: Characteristics, problems and prospects". Advances in Management 2(1), 112-122. 
Agboli, M. \& Ukaegbu, C. C. (2006), "Business environment and entrepreneurial activity in Nigeria: Implications for industrial development", Journal of Modern African Studies. 44(1), 1-30.

Agwu, M. O. \& Emeti, C. I. (2014), "Issues, challenges and prospects of small and medium scale enterprises (SMEs) in Port Harcourt City, Nigeria”. European Journal of Sustainable Development, 3(1), 101 - 114.

Akpedji, G. (2015), "YouWin awardees protest non-payment of second third trenches", Guardian newspaper, November 7, Accessed from http://www.ngrguardiannews.com.

Ashmore, M., C. (1989), “The Power of Entrepreneurship Vision,” Vocational Education Journal. (64) 186.

Anigbogu, T.U, Edoko, T.D, Okoli, I. M. (2016), "Foreign Direct Investment and Poverty Reduction in Nigeria", International Journal of Business and Management Invention, 5(6), 19-28.

Ariyo, D. (2005), "Small firms are the backbone of the Nigerian economy". Accessed from http://www.africaeconomicanalysis.org.

Atawodi, O. W. \& Ojeka, S. A. (2012), "Factors that affect tax compliance among small and medium enterprises (SMEs) in north central Nigeria" International Journal of Business and Management, Vol. 7(12), 87-96.

Audretsch, D. B., Grilo, I., \& Thurik, A. R. (2007), "Explaining entrepreneurship and the role of policy: A framework". In Audretsch, D. B., Grilo, I., \& Thurik, A. R. (eds.), The handbook of research on entrepreneurship policy (pp. 1-17). UK: Edward Elgar Publishing.

Baba S, Dickson V, Kromtit M. (2014), "Entrepreneurship and employment generation in Nigeria a case study, National Directorate of Employment (NDE)". 6(2), 40-58.

Bornstein, A. F. \& Davis, O. (2010), "Innovation to address social challenges". Workshop proceeding, http://www.oecd.org/sti/inno/47861327

Bula, H.O. (2012), "Evolution and theories of entrepreneurship: A critical review on the Kenyan perspective", International Journal of Business and Commerce, 1(7), 81-96.

Duru, M. (2011), "Entrepreneurship opportunities and challenges in Nigeria". Business and Management Review $1(1), 41-48$.

Ekwem, I. (2011), "Small and Medium Scale Enterprises Development in Nigeria: Constraints and Policy Options", (Doctoral dissertation, Stellenbosch: Stellenbosch University).

Etuk, R. U, Etuk, G. R. and Baghebo, M. (2014), "Small and medium scale enterprises (SMEs) and Nigeria's economic development". Mediterranean Journal of Social Sciences, 5(7), 656 -662

Friedman, B. A., (2011), "The Relationship between Governance Effectiveness and Entrepreneurship". International Journal of Humanities and Social Science, 1(17), 221.

Gangi, Y.A. and Timan, E. (2013), "An Empirical Investigation of Entrepreneurial Environment in Sudan", World Journal of Entrepreneurship, Management and Sustainable Development. 9(2/3), pp. 168-177.

Gbandi, E. C. \& Amissah, G. (2014), "Financing options for small and medium enterprises (SMEs) in Nigeria". European Scientific Journal, 10 (1), 327-340

Hamilton, B. H. (2000), "Does entrepreneurship pay? An empirical analysis of the returns to self-employment", Journal of Political Economy, 108(3), 601 - 631.

Henslin, J. M. (2003), Social problems (sixth edition). USA: Allyn \& Bacon.

Hussain, A. \& Norashida, D. (2015). Impact of entrepeurial intention of Pakistan students, Journal of entrepreneurship and business innovation, 2(1), 43-53.

Idam, L.E. (2014), "Entrepreneurship development in Nigeria: A review”. Journal of Business and Management, 16(1), 01-07.

Ihugba, O. A; Odii, A. \& Njoku, A. C. (2013), "Challenges and prospects of entrepreneurship in Nigeria", Academic Journal of Interdisciplinary Studies, 2(5), 25 - 26.

Ihugba, O.A., Odii, A., and Njoku, A., (2014), "Theoretical Analysis of Entrepreneurship Challenges and Prospects in Nigeria", International Letters of Social and Humanistic Sciences, 5, 21-34.

Manis, J. G. (1976), "Social protection in Nigeria: Mapping Programmes and Their Effectiveness". ODI/UNICEF Nigeria.

Misango \& Ongiti (2013), "Do Women Entrepreneurs Play a Role in Reducing Poverty? ACase in Kenya", International Review of Management and Business Research, 2 (1),

Mohammed, U. D. \& Ndulue, I. (2017), "Impact of Social Entrepreneurship on Poverty Reduction in Nigeria: a Study of Wecyclers Social Entrepreneurship Ltd", International Journal of Development Strategies in Humanities, Management and Social Sciences, 7(3), 63-73.

Moghimi, M. (2008), "Stimulating entrepreneurial development” Entrepreneur Magazine.1 (2), 4-8.

National Directorate of Employment (1986), "National directorate of employment program of action, an information bulletin". Abuja Nigeria.

National Bureau of Statistics (2012), Annual Abstract of Statistics. www.Nigeriastate, gov.ng.

Ndubuisi-Okolo P. U, and Anigbuogu, T. (2019), "Insecurity in Nigeria: the Implications for Industrialization and Sustainable Development". International Journal of Research in Business Studies and Management, 6(4), 7-16. 
National Entrepreneurship Development Programme (NEDEP) (2014). National entrepreneurship development programme: NEDEP- Release 1.0.http://www.nac.org.ng/NEDEP.pdf.

National Industrial Revolution Plan (NIRP) (2014), National industrial revolution plan: NIRP-Release 1.0. http://www.nac.org.ng/NIRP.pdf.

Obaji, N. O. \& Olugu, M. U. (2014), "The role of government policy in entrepreneurship development”, Science Journal of Business and Management 2(4), 109-115. http://doi.org/10.11648/j.sjbm.20140204.12.

Ocheni, S. I. \& Gemade, T. I. (2015), "Effects of multiple taxation on the performance of small and medium scale business enterprises in Benue State", International Journal of Academic Research in Business and Social Sciences, 5(3), $345-364$.

Okeke, M. I. \& Eme O. I. (2014), "Challenges facing entrepreneurs in Nigeria", Singaporean Journal of Business Economics and Management Studies, 3(5), 18-34

Olajide, O. T. (2004), The Theories of Economic development and Planning. Pumark Nigeria Ltd.

Oloyede, B. B. (2014), "Effect of Poverty Reduction Programmes on Economic Development Evidence from Nigeria", Arabian Journal of Business and Management Review, 4(1), 26-37.

Omoniyi, M. B. I. (2013), "The Role of Education in Poverty Alleviation and Economic Development: A Theoretical Perspective and Counselling Implications", British Journal of Arts and Social Sciences, 15(2), 176-185.

Osotimehin, K. O; Jegede, C. A; Akinlabi, B. H. \& Olajide, O. T. (2012), “An evaluation of the challenges and prospects of micro and small scale enterprises development in Nigeria". American International Journal of Contemporary Research, 2(4), 174 - 185.

Potterovich, V. \& Popov, V. (2012), Stages of Development, Economic Policies and a New World Economic Order. MPRA Paper 20055, University Library of Munich, Germany

Praag, C.M.V. \& Versloot, P.H. (2007), "What is the value of entrepreneurship?" IZA Discussion Paper No. 3014. Retrieved from ftp.iza.org/dp3014pd.

Prahalad, N. \& Hammond, K. (2002), "Growth, inequality and Poverty Reduction in Developing Countries: recent global evidence”. OECD Development Centre, Background Paper for the Global Development Outlook 2010 Shifting Wealth: Implications for Development

Sachs, J. D. (2009), The end of poverty, Economic Possibilities of our time. New York: The Penguin Press.

Sanusi, J. O. (2003), "Overview of Government's Efforts in the Development of SMEs and the Emergence of Small and Medium Industries Equity Investment Scheme (SMIEIS)”. Being a paper presented at The National Summit On Smieis Organised by the Bankers' Committee and Lagos Chambers Of Commerce And Industry (LCCI), Lagos On 10th June, 2003. Accessed from https://www.cbn.gov.ng/OUT/SPEECHES/2003/GOVADD-10BJUNE.PDF

Salami, C.G.E. (2013), "Youth unemployment in Nigeria: A time for creative intervention", International Journal of Business and Marketing Management, 1 (2), 18-26.

Schumpeter, J. A., (1989), The Theory of Economic Development, Cambridge (Mass): Harvard University Press.

Schumpeter, J. A. (1934), The theory of economic development. Cambridge, MA, US: Harvard University Press.

Schumpeter, J.A. (1961), The Theory of Economic Development. New York: Oxford University Press.

Scherer, F. M. (1999), New perspectives on economic growth and technological innovation. Washington, DC: Brookings Institution Press.

Stevenson, 1. \& Lundström, A. (2001), Patterns and trends in entrepreneurship/SME policy and practice in ten economies. Swedish Foundation for Small Business Research.

Storey, D. J. (2008), Entrepreneurship and SMEs Policies. Warwick Business School: World Entrepreneurship Forum.

Tende, S. B. A. (2014), Government Initiatives toward Entrepreneurship Development in Nigeria, Global Journal of Business Research, 8(1), 109-120.

Thaddeus, E. (2012), Perspectives: entrepreneurship development \& growth of enterprises in Nigeria. Entrepreneurial Practice Review, 2(2), 31-35.

Today, $\mathrm{Ng}$ News Bulletin retrieved online from https:/www.today.ng/tag/government-enterpriseandempowerment-programme.

World Bank (2017), Migration and Remittances. Accessed from www.worldbank.org/en/topic/labormarkets/brief/migration-and-remittances. 